\title{
COPEPOD AND NEMATODE PARASITES OF THE THREE-SPOTTED DAMSELFISH Dascyllus trimaculatus FROM BIDONG ISLAND, TERENGGANU
}

\author{
PEI YING LEE, YUSRI YUSOF AND MELISSA BEATA MARTIN*
}

Faculty of Science and Marine Environment, Universiti Malaysia Terengganu, Terengganu, Malaysia

* Corresponding author:melissa.martin@umt.edu.my

http://doi.org/10.46754/umtjur.2021.01.002

\begin{abstract}
This study focuses on the parasites in Dascyllus trimaculatus fish in Bidong Island. Though $D$. trimaculatus is a common reef fish, there is lack on parasites studies of this fish in Malaysia. The objectives of this study are to identify metazoan parasites and analyse the prevalence and mean intensity the parasites in D. trimaculatus. Sampling was randomly conducted on a coral colony of 100 meters within a $15 \mathrm{~m}$ depth at Pantai Pasir Cina, Bidong Island. This research resulted in the identification of a copepod Lernaeocera branchialis and a nematode from the family Camallanidae. The copepods collected in this study infected 20 out of 42 D. trimaculatus specimens, whereas the nematode-like parasites collected infected 18 of out of 42 D. trimaculatus. All copepods found in the gills of D. trimaculatus had a prevalence of 4.95 and mean intensity of $47.62 \%$, while the nematode-like parasite, which were found in the brain, had 2.72 prevalence and $42.86 \%$ mean intensity. This elucidates that both parasites are categorised as having light level but common frequency of infection, and the current IUCN status of D. trimaculatus has not been reported to be harmed by parasites. Though the mean intensity of both parasites is not harmful, the prevalence are concerning and might increase in the future, with further incorporation and monitoring of climate change factors that may affect the damselfish.
\end{abstract}

Keywords: Three-spotted damsel, nematode parasite, Lernaocera branchialis, prevalence, mean intensity.

\section{Introduction}

Bidong Island is located in the eastern side of the Peninsular Malaysia and forms part of the Bidong Archipelago. Its locality at the South China Sea (SCS) nurtures high coral reef cover, resulting in a diversified coral ecosystem. Despite its high diversity, there is still a lot of the archipelago that requires much needed study. For one, coral health monitoring should be constantly executed, as poor environmental conditions can encourage excessive algal growth and colonisation of algal turfs (McCook et al., 2001). To date, the coral ecosystem of Bidong Island is composed of myriad of fish communities of various trophic levels to cater to a "check and balance" of the ecosystem health. Of the many contributors, the damselfish (which are planktivorous fish) plays an important role in the coral reef ecosystem (Gladstone, 2007), as they often feed on epilithic algae, which grows on coral rubble (Wilson \& Bellwood, 1997).

Dascyllus are famous as aquarium fish, therefore the high demand results in overharvesting, which is destructive to the fish and the coral ecosystem ( $\mathrm{Sin}$ et $a l$, 1994). The excessive harvest of coral reef fishes could cause unrecoverable of population (Sin et al., 1994). In Malaysia, the damselfish is endangered because of illegal harvest and habitat destruction (Sin et al., 1994; Allen et al., 2010; Robertson et al., 2010; Jenkins et al., 2012; Allen \& Robertson, 2015; Jenkins et al., 2017). The fishes were seen in lower populations on dead coral as compared to live coral (Sin et al., 1994). In IUCN Red List, there are 128 species of damselfish are listed. Among 28 species of damselfish, 17 species are 
data deficient and least concern, 2 species are near threatened (Allen \& Robertson, 2015; Robertson et al., 2010), 7 species are vulnerable (Jenkins et al., 2017; Allen et $a l ., 2010), 1$ species is endangered (Jenkins et al., 2012), and one species is critically endangered (Allen et al., 2010).

In Bidong Island, damselfish ranks as one of the highest percentage composition of fish population (Rumeaida et al., 2014). They feed on small crustaceans and plankton on top of the known epilithic algae (Gladstone, 2007). Damselfish can prove to be important algal regulators by feeding on algae mat that causes poor survivorship and altered growth of Acropora (Wilson \& Bellwood, 1997; Potts, 1977). It has been known that algae could overgrow and suffocate coral, causing coral death and directly dwindling the number of damselfish communities in the reef, as they are seen to be more abundant at live coral areas (Sin $e t$ al., 1994). Among the top 5 most abundant damselfish species in Bidong Island, two Dascyllus fish species are present in the waters: Dascyllus reticulatus and Dascyllus trimaculatus of which the latter is the study subject for parasites.

With regards to parasites, though naturally known for its detrimental effects, they play an important role as regulators (Marcogliese, 2002). Parasites could also alter the food chain, by changing in their prevalence and density in long term and reduce host numbers (Marcogliese, 2002). The studies of parasites on Dascyllus fishes are not common in Malaysia. Of the known listed literature from Malaysia (see Sin, et al., 1994; Andersson, 2002; Chen et al., 2004; Rumeaida et al., 2014; Arai, 2015), most pertain on the diversity, disturbance, and conservation measures of the population.

This study focuses on the identification of parasites' species on D. trimaculatus and their prevalence and mean intensity. As the two known Dascyllus species in Bidong Island are abundant and to date least concerned according to IUCN, there are other facets that needs enlightenment to ensure the holistic biology and sustainability of the Dascyllus population.

\section{Materials and Methods}

\section{Sampling Area}

The sampling for this study was conducted at Bidong Island, which is a research station acquired by Universiti Malaysia Terengganu. The island is located at South China Sea, Malaysia (Figure 1). The South China Sea is noted for its highly productive ecosystem and rich in diversity (Matsunuma et al., 2011). The sampling area was on the coral reef area in front of Pantai Pasir Cina. The fish specimens were collected within 10 meters depth for safety purposes. 


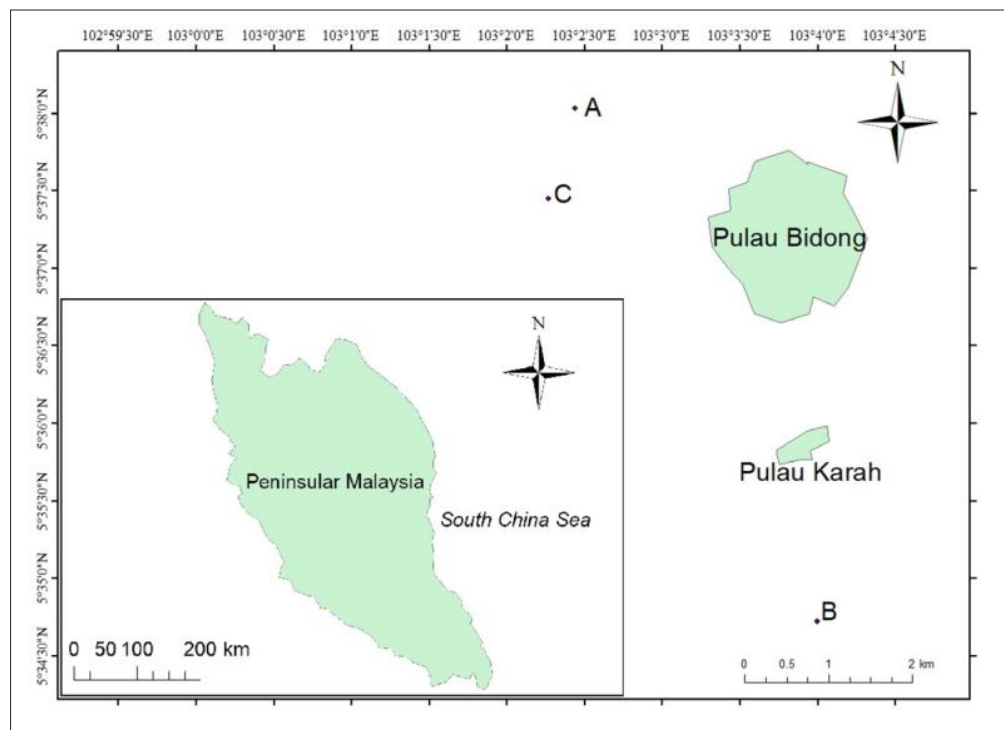

Figure 1: Bidong Island Marine Research Station, South China Sea, Malaysia $\left(5.62^{\circ} \mathrm{N}, 103.07^{\circ} \mathrm{E}\right)$.

The red circled area indicates the sampling done offshore Pantai Pasir Cina

\section{Sampling and Fish Collection}

Divers equipped with scuba diving gears collected the fish host specimens. Clove oil extract was administered via close exposure of the fishes near the coral colonies and worked as a sedative to collect the damsel fishes. The sedated fishes were collected using 2 feet long scoop net. The sampled fishes were being kept in ice chest with ice and salt to euthanise them humanely. A total of 42 D. trimaculatus were collected. The identification of fish was confirmed based on Matsunuma et al (2010). Fish length and weight measurement were recorded. Each fish was placed into separate labelled zipper bags to prevent any cross-contamination of individual hosts.

\section{Parasitological Examination}

The fishes' external anatomies were examined, including skin, operculum, gills, eyes and mouth cavity while the fish samples were still fresh. Dissection of fish was initiated by cutting open the anus to the operculum, cutting upward from anus to the operculum to expose the organs. The muscle, which connects operculum, was removed (Gupta \& Mullins, 2010). Internal organs removed and placed on a petri dish. The fish muscle was cut open to examine the muscles under dissecting microscope Olympus SZX7 and Carl Zeiss Stemi DV4 for any apparent cyst or moving parasites and compound microscope Olympus SZX7 with an attached camera Lucida for observing other smaller parasites (e.g., nematodes). The brain mass with diluted with distilled water on pressed on a glass slide using a cover slide. Every parasite sample obtained was preserved in 70\% ethanol and labelled separately according to Berland (1984). The calculation of prevalence and mean intensity follows Bush et al. (1997). Images of the parasites were captured using DinoEye $\mathrm{C}$ piece camera mounted on the abovementioned dissecting microscopes. For identification of various parasitic groups in damselfish, the authors referred to Lo (1999), Lo and Morand (2000), Nagel and Grutter (2007), Gunter and Adlard (2008), Sasal and Gadenne (2017) and, Santos and Sikke (2017). 


\section{Results and Discussion}

\section{Fish Collection Data}

A total of 42 D. trimaculatus were sampled at Pantai Pasir Cina, Bidong Island. Table 1 shows the weight and length data of $D$. trimaculatus sampled. The mean weight was 5.30 grams and the mean length was $4.87 \mathrm{~cm}$. The Dascyllus sampled were fairly small, in comparison to the $11 \mathrm{~cm}$ standard length recorded in Matsunuma et al., (2011).

Table 1: Total number, minimum, maximum, mean, standard deviation of weight and length of $D$. trimaculatus

\begin{tabular}{lccccc}
\hline Dascyllus trimaculatus & N & Minimum & Maximum & Mean & $\begin{array}{c}\text { Standard } \\
\text { Deviation }\end{array}$ \\
\hline Weight $(\mathrm{g})$ & 42 & 0.10 & 43.80 & 5.30 & 7.48 \\
Length $(\mathrm{cm})$ & 42 & 2.40 & 12.20 & 4.87 & 2.05 \\
\hline
\end{tabular}

Nematode parasite from the family Camallanidae (Railliet \& Henry, 1915)

Phylum: Nematoda

Class: Chromadorea

Order: Rhabditida

Family: Camallanidae

Site of infection: Brain

Prevalence of infection: $42.86 \%$ (18 out of 42 fishes were infected)

Mean intensity: 2.72

\section{Diagnostic Remarks:}

Fourty nine nematode specimens from the family Camallanidae were found specifically in the brain (Figures 2 and 3).
Species identification posed a challenge due to the lack of obvious external morphology characteristics present such as lip region, eosophageal lumen, intestine, rectum, excretory pore, and tail. The nematodes were small even under microscope ranging $0.075-0.120 \mathrm{~mm}$. The nematodes had a distinct split-end (as seen in Figure 3), suggesting that it belongs to the family Camallanidae (order Rhabditida). Males from the family Camallanidae are known to have two spicules, with some species being hardly visible and could be absent (Santos \& Moravec, 2009). Camallanid nematodes are parasites that mainly infects the stomach and intestines (Anderson, 2000), thus finding these nematode parasites in the brain of $D$. trimaculatus is highly unusual.

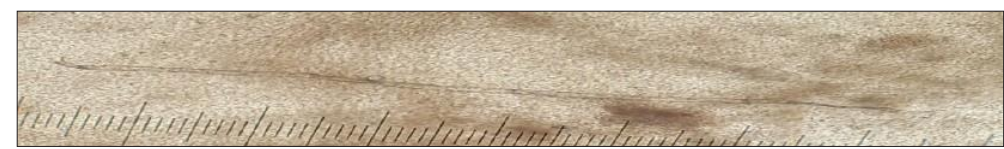

Figure 2: A nematode parasite likely from the family Camallanidae under microscope magnification $10 \mathrm{X}$
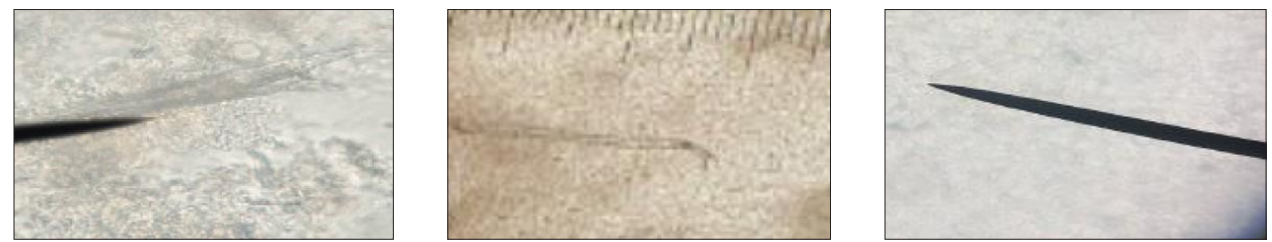

Figure 3: The nematode parasite has two spicules at tail, the parasites found has one split end, which is similar to the description of Camallanidae (scale bar $0.05 \mathrm{~mm}$ ) 
Copepod parasites Lernaeocera branchialis (Linnaeus, 1767)

Phylum: Arthropoda

Class: Hexanauplia

Order: Siphonostomatoida

Family: Pennellidae

Species: Lernaeocera branchialis

\section{Site of infection: Gills}

Prevalence of infection: $47.62 \%$ (20 out of 42 fishes were infected)

Mean intensity: 4.95

\section{Diagnostic Remarks:}

Ninety-nine Lernaeocera branchialis specimens (Figure 4) were collected from the host's gills. The species is readily diagnosed according to the following features: the cephalothorax has a pair of antennules, which the antennules are foursegmented; a pair of antennae present, at ventrally and posterior of the antennules; the buccal tube is present posterior to the antennae. The copepodid has a frontal filament, which is different compared to other siphonostomatid parasites. Its frontal filament diverges into two when penetrates the host's tissue. While the body of $L$. branchialis consists of four pairs of swimming legs, six thoracic somite, included genital segment, and lastly its caudal rami (Brooker, 2007).

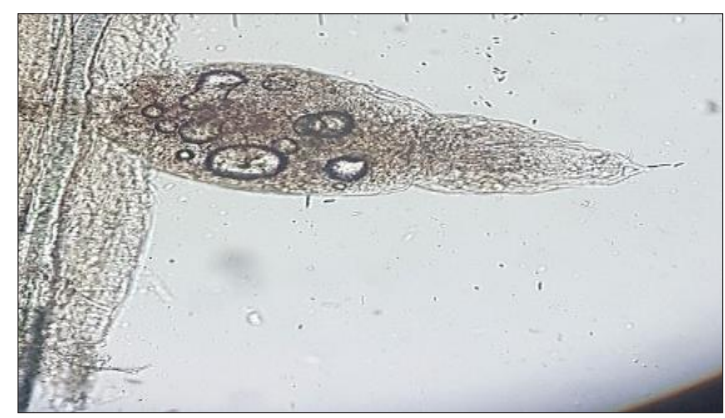

Figure 4: Circled is the frontal filament of L. branchialis. Abbreviations: c, cephalothorax; L1, first swimming leg; L2, second swimming leg; L3, third swimming leg; gs, genital segment; cr, caudal rami (scale bar $0.15 \mathrm{~mm}$ )

\section{Discussion}

\section{Parasites of damsel fishes worldwide}

Records on parasites of Dascyllus fish worldwide are poorly reported (Table 2). Of the many studies, focus mainly pertains to Dascyllus aruanus and D. reticulatus coming from Australia and French Polynesia, and one report of $D$. trimaculatus from the Philippines. The most reported parasites coming from the host genus Dascyllus were monogeneans (family Dactylogyridea), crustacean isopods (family Gnathidae) and one report of myxozoan parasite.
Based on available literature of parasites from D. trimaculatus, it was reported that the host collected from the Phillipines (Santos \& Sikke, 2017) were parasitised by gnathid crustaceans. In comparison to our study, our hosts were void of these gnathid parasites, thus our findings of the copepod and nematode parasite represent new records of host-parasite association. We further elaborate on the specifics of these parasites under sections "Nematode parasites of D. trimaculatus from Bidong Island" and "Copepod parasites of D. trimaculatus from Bidong Island”. 
Table 2: List of studies on Dascyllus fish's parasites worldwide and current research

\begin{tabular}{|c|c|c|c|c|}
\hline Dascyllus host & Parasites & Infected organs & Location & Reference \\
\hline D. aruanus & $\begin{array}{l}\text { Monogenea } \\
\text { Dactylogyridea: } \\
\text { Haliotrema }\end{array}$ & Gills & $\begin{array}{l}\text { Mo'orea } \\
\text { Island, French } \\
\text { Polynesia }\end{array}$ & Lo, 1999 \\
\hline D. aruanus & $\begin{array}{l}\text { Myxozoa } \\
\text { Bivalvulida: } \\
\text { Myxidiidae }\end{array}$ & Gall bladder & $\begin{array}{l}\text { Great Barrier } \\
\text { Reef, Australia }\end{array}$ & Gunter \& Adlard, 2008 \\
\hline $\begin{array}{l}\text { D. aruanus } \\
\text { D. reticulatus }\end{array}$ & $\begin{array}{l}\text { Crustacean } \\
\text { Isopod: } \\
\text { Gnathiidae }\end{array}$ & Skin & $\begin{array}{l}\text { Great Barrier } \\
\text { Reef, Australia }\end{array}$ & Nagel \& Grutter, 2007 \\
\hline D. aruanus & $\begin{array}{l}\text { Monogenea } \\
\text { Dactylogyridea: } \\
\text { Haliotrema }\end{array}$ & Gills & $\begin{array}{l}\text { Opunohu } \\
\text { Bay, Mo'orea } \\
\text { Island, French } \\
\text { Polynesia }\end{array}$ & $\begin{array}{l}\text { Sasal \& } \\
\text { Gadenne, } 2017\end{array}$ \\
\hline D. aruanus & $\begin{array}{l}\text { Monogenea } \\
\text { Dactylogyridea: } \\
\text { Haliotrema }\end{array}$ & & $\begin{array}{l}\text { Mo'orea } \\
\text { Island, FrencH } \\
\text { Polynesia }\end{array}$ & Lo \& Morand, 2000 \\
\hline D. trimaculatus & $\begin{array}{l}\text { Crustacean } \\
\text { Isopod: } \\
\text { Gnathiidae }\end{array}$ & Gills & $\begin{array}{l}\text { Negros Oriental, } \\
\text { Philippines }\end{array}$ & Santos \& Sikke, 2017 \\
\hline D. trimaculatus & $\begin{array}{l}\text { Crustacean } \\
\text { Copepod: } \\
\text { Pennelidae } \\
\text { Camallanid } \\
\text { nematode }\end{array}$ & $\begin{array}{l}\text { Gills } \\
\text { Brain }\end{array}$ & Bidong Island & Current study \\
\hline
\end{tabular}

\section{Nematode parasites of Dascyllus trimaculatus from Bidong Island}

The family Camallanidae that were found in reef-associated fish were reported to have wide geographical distribution and host species range (Rigby et al., 1997). It is not common for nematode to infest the brain of fish, and Camallanidae does not infest brain of fish. Therefore there is a possibility this case is an accidental parasitism as that of Martin's et al. (1970). The author recorded the presence of nematode which infects human has infected the brain of marine mammals. The nematode could not be identified, as a fully mature worm were not available except for unfertilized nematode eggs. Martin et al. (1970) suggested that the mammals were infected by ingestion of infected organisms.

\section{Copepod parasites of Dascyllus trimaculatus from Bidong Island}

Lernaeocera branchialis has two hosts in its life cycle, an intermediate host and a definitive host. The two nauplius stage are free swimming zooplankton, suggesting that L. branchialis is not host specific. Following the nauplius stage is an infective copepodid stage. The copepod will then start to find the intermediate host in their four chalimus stage. The intermediate host for the chalimus stages would be demersal fish and it is usually flounders (Brooker et al., 2007). The copepod will have to find a definitive host to continue its mature adult stage. During the sampling of $D$. trimaculatus, the depth of water was lesser than 15 meters. As mentioned above, intermediate host of L. branchialis are demersal fish and the fact 
that Pantai Pasir Cina is present in shallow waters, this would allow ease of infestation of $L$. branchialis towards D. trimaculatus. Findings of L. branchialis being pathogenic on small fish and have been reported to have minimal effect but not depending on the fish length (Knudsen \& Sundnes, 1998). Dascyllus trimaculatus is small and $L$. branchialis were found on them with light level of infestation and common frequency of infestation.

It is suggested that D. trimaculatus is not the definitive host. This is because there is no egg bearing of female of $L$. branchialis found. The mature female $L$. branchialis would not undergo metamorphosis into adult stage of gravid form unless it is in the definitive host (Brooker et al., 2007). The definitive host is usually gadoid fish (Boxshall, 1974). There were many studies on L. branchialis, which appeared to commonly infest gadoid fish (Kabata, 1961; Brooker, 2007; Brooker et al., 2007). These studies mostly took place in Atlantic waters, where gadoid fish geographically occur due to temperate waters. Malaysia being in tropical waters are void of these gadoid fish. Furthermore, although Lernaeocera were found more prevalent in inshore waters, they appear to be limited in distribution in warmer waters, preferring temperatures below 20 (Brooker et al., 2007).

In an interesting case study in the tropical waters of Bali, Indonesia, Kleinertz (2014) recorded the presence of a pennelidae copepod on the host of Epinephelus areolatus, a reef-associated grouper. Matsunuma (2011) has recorded Epinephelus areolatus, a reef-associated grouper in waters of Terengganu. We could contemplate that Lernaeocera could use Epinephelus as a definitive host (in comparison to gadoid fishes of the temperate waters) since Bali and Terengganu occur in tropical waters and both geographical regions are present of the Epinephelus species. It would garner much interest to further investigate on the above hypothetical approach of the life cycle of Lernaeocera and its use of various hosts.

\section{Preliminary evidence observation of host size association with parasite}

The ectoparasite copepods in this study have noticeably higher prevalence and mean intensity as compared to the nematode endoparasite. This comes to no surprise since ectoparasites live in the outer region of host, and have higher chances of area availability to infest, thus the parasite size correlates positively with prevalence and mean intensity (Poulin, 1999). Large endoparasites are expected to have low mean intensity as they have limited space to grow and reproduce (Poulin, 1999). Both prevalence and mean intensity of ectoparasites could be expected to correlate with the increase in size of host. If the space availability for attachment is larger, the intensity can increase as there is more space to infest, thus the prevalence could be affected as well (Brooker, 2007). However, the copepod in our study were not affected by the increase of size and weight of the fish. Most of the infested fishes were small to average-sized, ranging between

2.4 to 6.4 grams. Poulin (1999) recorded in Sasal et al. (in press) stated there is no relationship between ectoparasite body size and prevalence in fish.

The nematode parasite number did not increase with the fish size and weight. Poulin (1999) stated that large nematode should be correlating positively with prevalence but negatively with intensity of infection. They infest higher number of fishes but low numbers per host, as they can produce more eggs. On the other hand, small nematodes could have high intensity in host (Poulin, 1999). The nematodes were mostly found on the smaller fish, but none infects big fishes. Our evidence is in agreement to Poulin's (1999) hypothesis, where ectoparasites were predicted to have low intensity but high prevalence. 


\section{Conclusion}

The research of parasites on Dascyllus fishes in Malaysia needs to be looked into more thoroughly as parasites studies on coral fish in general are still very limited, and to overrule any possibilities of parasites affecting these fragile communities. Most of the previous studies on parasites on Dascyllus fishes worldwide resulted in many of the parasites infecting the gills and skin of Dascyllus fish. As show in this study and previous records, there are most likely more ectoparasites on coral reef fish compared to endoparasite due to the sheer size of the host.

This study's finding is concerning, as the frequency of prevalence of L. branchialis and nematode from the family Camallanidae is at a common stage although the level of infection is light, in comparison to previous studies where only isopod crustaceans and monogeneans were found on Dascyllus. However, incorporating molecular tools for identification will further elucidate the species of parasites we are dealing with specifically, and will portray better means of the vulnerability of the Dascyllus fishes's biology and means for conservation.

\section{Acknowledgements}

The authors would like to thank Mr Che Mohd Zan bin Husin for his assistance in the use of equipment, consumables and other facilities at the Biodiversity Laboratory (MBIO), Faculty of Science and Marine Environment.

\section{References}

Allen, G. \& Robertson, R. (2015). Stegastes baldwini [online]. The IUCN Red List of Threatened Species 2015: e.T183961A85699047. Retrieved from http://dx.doi.org/10.2305/IUCN. UK.2015.RLTS.T183961A85699047. en.
Allen, G., Robertson, R., Rivera, R.,Edgar, G., Merlen, G., Zapata, F. \& Barraza, E. (2010). Azurina eupalama [online]. The IUCN Red List of Threatened Species 2010: e.T184017A8219600. Retrieved from http://dx.doi.org/10.2305/IUCN. UK.2010-3.RLTS.T184017A8219600. en.

Anderson, R. C. (2000). Nematode parasites of vertebrates: Their development and transmission. Cabi.

Andersson, K (2002). A study of coral reef fishes along a gradient of disturbance in the Langkawi archipelago, Malaysia. Undergraduate Thesis, Uppsala University, Uppsala. 5-38.

Arai, T. (2015). Diversity and conservation of coral reef fishes in the Malaysian South China Sea. Reviews in Fish Biology and Fisheries, 25(1), 85-101.

Berland, B. (1984). Basic techniques involved in helminth preservation. Systematic Parasitology, 6(4), 242245.

Boxshall, G. A. (1974). Infections with parasitic copepods in North Sea marine fishes. Journal of the Marine Biological Association of the United Kingdom, 54(2), 355-372.

Brooker, A. J., Shinn, A. P., \& Bron,

J. E. (2007). A review of the biology of the parasitic copepod Lernaeocera branchialis (L., 1767) (Copepoda: Pennellidae). Advances in Parasitology, 65, 297-341.

Brooker, A. J. (2007). Aspects of the biology and behaviour of Lernaeocera branchialis (Linnaeus, 1767) (Copepoda: Pennellidae). Ph.D. dessertation. University of Stirling, Scotland.

Bush, A. O., Lafferty, K. D., Lotz, J. M., \& Shostak, A. W. (1997). Parasitology meets ecology on its own terms: Margolis et al. revisited. The Journal of Parasitology, 575-583. 
Chen, C.A., Ablan, M.C.A., McManus J.W., Bell, J.D., Tuan, V.S., Cabanban, A.S., Shao, K.Tsao (2004). Variable numbers of tandem repeats, heteroplasmy, and sequence variation of the mitochondrial control region in the three spot Dascyllus, Dascyllus trimaculatus (Perciformes:Pomacentridae). 43, 803812.

Gladstone, W. (2007). Selection of a spawning aggregation site by Chromis hypsilepis (pisces: Pomacentridae): habitat structure, transport potential, and food availability. Marine Ecology Progress Series, 351, 235-247.

Gunter, N. L., \& Adlard, R. D. (2008). Bivalvulidan (Myxozoa: Myxosporea) parasites of damselfishes with description of twelve novel species from Australia's Great Barrier Reef. Parasitology, 135(10), 1165-1178.

Gupta, T., \& Mullins, M. C. (2010). Dissection of organs from the adult zebrafish. JoVE (Journal of Visualized Experiments), (37), e1717.

Jenkins, A., Myers, R. \& Rocha, L. A. (2012). Neopomacentrus aquadulcis [online]. The IUCN Red List of Threatened Species 2012: e.T188319A1857376. Retrieved from http://dx.doi. org/10.2305/IUCN.UK.2012.RLTS. T188319A1857376.en.

Jenkins, A., Carpenter, K.E., Allen, G. \& Yeeting, B. (2017). Amblyglyphidodon batunai [online]. The IUCN Red List of Threatened Species 2017: e.T188528A1888295. Retrieved from http://dx.doi.org/10.2305/IUCN. UK.2017 2.RLTS.T188528A1888295. en.

Kabata, Z. (1961). Lernaeocera branchialis (L.) a Parasitic Copepod from the European and the American Shores of the Atlantic. Crustaceana. 2. 243-249. 10.1163/156854061X00211.
Kleinertz, S., Damriyasa, I. M., Hagen, W., Theisen, S., \& Palm, H. W. (2014). An environmental assessment of the parasite fauna of the reef-associated grouper Epinephelus areolatus from Indonesian waters. Journal of helminthology, 88(1), 50-63.

Knudsen, K. K., \& Sundnes, G. (1998). Effects of salinity on infection with Lerneaocera branchialis (L.) (Copepoda: Pennelidae). The Journal of Parasitology, 700-704.

Lo, C. M. (1999). Mating rendezvous in monogenean gill parasites of the humbug Dascyllus aruanus (pisces: Pomacentridae). The Journal of Parasitology, 1178-1180.

Lo, C. M., \& Morand, S. (2000). Spatial distribution and coexistence of monogenean gill parasites inhabiting two damselfishes from Moorea Island in French Polynesia. Journal of Helminthology, 74(4), 329-336.

Marcogliese, D. J. (2002). Food webs and the transmission of parasites to marine fish. Parasitology, 124(7), 83-99.

Martin, W. E., Haun, C. K., Barrows, H. S., \& Cravioto, H. (1970). Nematode damage to brain of striped dolphin, Lagenorhynchus obliquidens. Transactions of the American Microscopical Society, 200-205.

Matsunuma, M., Motomura, H., Matsuura, K., Shazili, N. A. M., Ambak, M. A., \& Meguro, M. (2011). Fishes of Terengganu: east coast of Malay Peninsula, Malaysia.

McCook, L., Jompa, J., \& Diaz-Pulido, G. (2001). Competition between corals and algae on coral reefs: a review of evidence and mechanisms. Coral Reefs, 19(4), 400-417.

Nagel, L., \& Grutter, A. S. (2007). Host preference and specialization in Gnathia sp., a common parasitic 
isopod of coral reef fishes. Journal of Fish Biology, 70(2), 497-508.

Potts, D. C. (1977). Suppression of coral populations by filamentous algae within damselfish territories. Journal of Experimental Marine Biology and Ecology, 28(3), 207-216.

Poulin, R. (1999). Body size vs abundance among parasite species: positive relationships?. Ecography, 22(3), 246250 .

Rigby, M. C., Font, W. F., \& Deardorff, T. L. (1997). Redescription of Camallanus cotti Fujita, 1927 (Nematoda: Camallanidae) from Hawai'i. The Journal of parasitology, 1161-1164.

Robertson, R., Allen, G. \& Lea, B. (2010). Azurina hirundo [online]. The IUCN Red List of Threatened Species 2010: e.T183774A8174674. Retrieved from http://dx.doi.org/10.2305/IUCN. UK.2010-3.RLTS.T183774A8174674. en.

Rumeaida, M. P., Daud, S. M., \& Badri, F. M. (2014). Fish diversity and abundance in Bidong Island, South China Sea, Malaysia. Aquaculture, Aquarium, Conservation \& Legislation, 7(3), 176183.
Santos, C. P., \& Moravec, F. (2009). Goezia spinulosa (Nematoda: Raphidascarididae), a pathogenic parasite of the arapaima Arapaima gigas (osteichthyes).

Santos, T. R. N., \& Sikkel, P. C. (2017). Habitat associations of fish-parasitic Gnathiid isopods in a shallow reef system in the central Philippines. Marine Biodiversity, 1-14.

Sasal, P. \& Gadenne, J. (2017). Testing the effect of parasites on coral reef fishes recruitment. Vie Et Milieu-Life and Environment, 67(2), 131-138.

Sin, T. M., Teo, M. M., Ng, P. K., Chou, L. M., \& Khoo, H. W. (1994). The damselfishes (pisces: osteichthyes: Pomacentridae) of Peninsular Malaysia and Singapore: systematics, ecology and conservation. Hydrobiologia, 285(1-3), 49-58.

Wilson, S., \& Bellwood, D. R. (1997). Cryptic dietary components of territorial damselfishes (Pomacentridae, Labroidei). Marine Ecology Progress Series, 153, 299-310. 